In conclusion, it must be emphasized that the successful use of simulation programs in game management is entively dependent on true estimates of population parameters.

For short periods, perhaps as long as 5 years, such a program could well be an effective tool in management, but then it must be fed with new estimates of population parameters. These estimates will probably have to be elaborated with the help of air censuses in the initial stages of moose management, but experience from other fields of statistical application favours the possibility of using more indirect methods of counting, for example collection and evaluation of the observations of hunters.

Hopefully, a firm application of the results of population dynamics simulation will help to control our more or less exploding moose population, to the advantage of both moose and man.

\title{
MEAT PRODUCTION FROM MOOSE
}

\author{
J. HANSSON, G. MALMFORS \\ Dep. of Animal Breeding and Genetics \\ The Swedish University of Agricultural Sciences, \\ $S-75007$ Uppsala, Sweden
}

This investigation was undertaken in order to present actual data about the distribution of different tissues in moose carcasses of both sexes and of varying age.

The carcass weight of the half-year-old calves averaged nearly $80 \mathrm{~kg}$, indicating a high daily gain during the first grazing season. Carcass weight of old male moose exceeded $200 \mathrm{~kg}$. Most of the carcasses were lacking in depot fat and had little trim fat and tendons. The calves had a ligh proportion of bone compared with other animals. The proportion of lean meat reached 80 p. Ioo for adult moose. There was more lean and less bone in the forequarter than in the hind quarter, the fat content being the same. The high proportion of retail cuts, compared with beef, was mainly explained by the fact that $M$. quadriceps femoris is more developed in moose.

The consequences of an increased moose population and moose meat production are briefly discussed.

\author{
STUDIES ON BLOOD PROTEIN AND ENZYME POLYMORPHISMS \\ IN THE EUROPEAN MOOSE (Alces Alces)
}

\author{
R. K. JUNEJA, M. WILHELIMSON and S. BENGTSSON \\ Dep. of Arimal Breeding and Genetics, \\ The Sredish University of Agricultural Sciences, \\ $S$ - 750 o 7 Uppsala, Sweden
}

Io8 plasma samples and 50 hemolysate samples of European moose from different areas oi Sweden, Norway and Finland were analysed by horizontal polvacrylamide gel electrophoresis in a discontinuous buffer system (Tris-citrate-borate, $\mathrm{pH}$ 9.0). Acid starch gel electrophoresis was conducted for the resolution of plasma albumin. No variation was observed for albumin, postalbumin and transferrin. Two non-hemoglobin proteins in the hemolysate samples showed variant forms in five samples. Hemolysate samples were also analysed by starch gel electrophoresis for the typing of acid phosphatase (AcP), phosphoglucomutase (PGM), phosphohexose isomerase (PHI) and 6-phosphogluconate dehydrogenase (6-PGD). There was no variation observed for these enzymes except that one sample showed a PGM variant. The lack of blood protein variation in moose observed in this study was in accordance with the results of some earlier studies. Further studies are needed to investigate the causes of the homogeneity observed in the European moose. 